\title{
Plainer legal language in Canada
}

The following Resolution M-08-91 on Plain

Language Documentation was passed by the Canadian Bar Association at its meeting in Saskatchewan on 25-26 Feb 91:

\section{Resolution M-08-91 Plain Language Documentation}

WHEREAS in 1988, The Canadian Bar Association and the Canadian Bankers Association established a Joint Committee on Plain Language Documentation;

WHEREAS the mandate of the Joint Committee was to assess the use of English and French plain language in the legal profession and the financial services industry, to identify barriers to the use of plain language, to develop one or more prototype banking documents and to make recommendations relating to the greater use of plain language in legal and financial services documents;

WHEREAS the Report of the Joint Committee was received by Council at the 1990 Annual Meeting;

BE IT RESOLVED THAT The Canadian Bar Association adopt the following recommendations, contained in the Report of the Joint Committee:

\section{The Plain Language Process}

1. Plain language drafting should be viewed as a dynamic process rather than simply the mechanical application of static rules. Plain language drafting is an activity that requires skill. But this skill can be acquired through appropriate study and training.

\section{The Legal Profession}

2. Canadian law schools and Bar Admission courses should be urged to include a plain language drafting course in their curriculum in an effort to instruct law students on how to write better, more plainly, and more clearly.

3. Law Societies and bar associations should design and offer Continuing Legal Education courses on writing in plain language.
The Banks

4. Canadian Banks and other large organizations should require that their lawyers draft documents in plain language style.

5. Each large organization should develop a plain language policy in the writing of its forms and documents that are intended for consumer use.

6. The organization should appoint a small interdisciplinary committee to develop consumer forms. The first draft of any consumer form in an organization should be done by a person with plain language drafting training and experience.

7. Banks and other large organizations should ensure that all employees have access to writing skills courses that stress plain writing techniques, and should encourage their employees to take these courses.

\section{Governments}

8. The Joint Committee urges all governments in Canada to adopt plain language techniques in the drafting of legislation, regulations, and government forms, and in so doing, to set an example for commercial practice.

\section{The Plain Language Coalition}

9. Both CBA's should adopt a Joint Statement of Principles stressing the need for plain language documentation, undertaking to promote plain language documentation within their memberships and throughout the Canadian community, and inviting other segments of the business, legal community, and government to adhere to the Joint Statement of Principle.

10. Industry associations, law firms, and government departments that adhere to the Joint Statement of Principles would, in so doing, become members of "The Canadian Coalition For Plain Legal Language"/"La coalition canadienne pour la lisibilité juridique".

A list of the members of this coalition should be published from time to time by the Canadian Legal Information Centre. 
11. With the assistance of the Canadian Legal Information Centre, the Coalition should advocate the increased use of plain language drafting in Canada and serve as a resource to its members in the drafting of plain language documentation.

\section{CARRIED}

\section{English thrives best without protectionism, teachers say}

(Press release, National Council of Teachers of English)

Why do many teachers of English oppose the current movement to make English the official language of the United States? Because 'the aims and tactics of the language protection movement' and 'its potential consequences for students' worry many members of the profession, says Harvey A. Daniels. He is the editor of a new book on this controversy, developed by the Commission on Language of the National Council of Teachers of English.

In Not Only English: Affirming America's Multilingual Heritage, well-known scholars and teachers offer historical, linguistic and educational background on the issue that has sparked the current drive to amend state and federal constitutions to establish English as the official tongue. The authors contend that 'English-only' policies now in force in 16 states 'hold grave dangers for teachers and students of English' and for many other Americans. Among the twelve contributors are Dennis Baron, L. Elliot Judd, Roseann Dueñas Gonzalez, James C. Stalker, Geneva Smitherman, James Sledd, and Victor Villanueva, Jr.

In his lead essay, Daniels points to a paradox: while the United States has been plural and multilingual from its colonial beginnings, English has remained dominant out of civic necessity and now serves as a worldwide lingua franca. Nevertheless, the nation has seen a series of protectionist campaigns like the current efforts of the lobbying group U.S. English.

Daniels and other contributors point out that such efforts coincide with new waves of immigration, wars, or economic downturns that carry threats of unemployment. They say the ethnocentric rhetoric and negative stereotypes the campaigns produce are often trace- able to 'fear of the stranger' - new or 'enemy' population groups whom later generations often view as 'standard,' unhyphenated Americans. The authors warn that Englishonly campaigns foster a destructive antiimmigrant climate that isolates newcomers and denies them help with English. Analyzing the effects of a long-standing English-only law in Illinois, Dennis Baron contends it has delayed efforts to understand the needs of non-English speaking students and has excused schools for letting them sink instead of helping them swim.

The authors discuss the potential threat English-only laws pose to civil rights legislation of recent decades, to legal, health, and voter assistance for language minorities, and to freedom to read and to teach. They charge that proponents of language restrictions ignore current knowledge about the origins and meanings of language differences and the process of language change.

Daniels urges teachers to support the concept of 'English Plus' - a richer curriculum for English including descriptive and historical study of the language, plus the learning of other languages and advocacy of greater language assistance for all learners.

Gonzalez observes that the U.S. English lobbying group has chosen the easier route to a constitutional amendment by shifting its campaign from Congress to the states. She warns that if it succeeds, options such as bilingual education for teaching non-English speakers would be restricted and immigrants' chances of employment reduced. Stalker predicts that a logical result of English-only laws would be 'standard English-only' laws and a quagmire of litigation over whose English is standard. Smitherman contends that omission of cultures other than Anglo from U.S. education leaves students unprepared to appreciate the 'singular achievement' of America in human history or to function 